\title{
Destruction for Use
}

Fanny Alice Coldren is reference librarian of the University of California at Los Angeles.

$\mathrm{T}$ HE MONOPOLY of public library facilities by students, as stated in the recent article by Roland Mulhauser, ${ }^{1}$ directs attention to a problem of long standing in college and university libraries, focusing particularly in the reference and periodical departments. How to provide and administer for the requirements of large classes certain materials often difficult to replace, and at the same time to preserve or replace those same materials for succeeding groups of students, is a problem not yet solved to the satisfaction of students, faculty, and librarians.

It is the purpose of this paper to present the experience of some institutions in their attempt to formulate policies and institute practices to meet this perplexing problem. This information is based upon correspondence with librarians of one hundred colleges and universities with student enrolments ranging from one thousand to over fifteen thousand representing various parts of the United States. The inquiry regarding practices of libraries covered the following points:

I. Has the library supplied copies of assigned articles, and if so, in what form and with what success?

2. Does the library or the department of instruction meet the expense of duplication?

1 Mulhauser, Roland. "Public Library Service to
College Students." Wilson Library Bulletin 15:249. College Students.
264, Nov. 1940.
3. Are duplicates administered by the reserve, the reference, or the circulation department?

4. Do library problems assigned to freshmen or other special groups create difficulties in the use of reference materials?

Sixteen institutions, with enrolments ranging from one to eight thousand students, reported that the problem does not exist or that it has not reached an acute point; one that no prohibitions have yet been made on duplicates used but the problem must be faced soon; another that plans are made for a survey of the situation.

Duplicated materials have been supplied in the form of typed or mimeographed copies, reprints, photostats, and in two institutions, microfilms. Typing is the most generally used method of reproduction and is done chiefly by N.Y.A. students, otherwise the lack of help and the cost of labor are too great to supply copies. One institution has abandoned the use of typing because the life of the copy is not commensurate with its cost, and another indicated that it will be necessary to do so if the demand continues to increase. Students in one college objected to typed copies because they were difficult to read.

The purchase of materials falls largely into two groups, namely, duplicate copies of individual numbers of periodicals, reprints, and pamphlets, and additional subscriptions to certain magazines required. The cost both of purchase and some form 
of duplication is met chiefly by the library, although some departments of instruction or individuals have supplied copies, which are administered by the library. The expense is charged to duplicate, replacement, periodical, textbook, department funds, and syllabi fees.

Dartmouth College purchases extra copies of magazines in accordance with the library's reserve book policy of providing one copy for every eight students. To acquaint freshman English students with general periodicals, Vanderbilt University buys from two to five copies of fourteen titles such as Harpers and the Atlantic, places them on reserve for a month, and discards them when the demand is over. The English department assumes the cost. In other institutions freshmen are required to purchase or subscribe to a magazine during one semester.

Classes in the social sciences require many pamphlets which some libraries buy in quantities. At St. Louis University the history department has assessed a fee of one dollar per semester to each student for the purchase of duplicates. These materials are generally textbooks other than the one assigned as basic and become the property of the library. The University of Washington divides the cost according to the length of the article; the circulation department reserves the right to determine whether the library or the department of instruction shall pay for the reproduction.

\section{Reference Books}

The problem as it applies to reference books is even more perplexing than that of periodicals and pamphlets. The repeated use of the same materials results in the loss of individual items in dictionaries, encyclopedias, and biographical dictionaries while the remainder of the volume and the set is still in good condition. The same is true of other books in which diagrams, charts, and statistical tables are omitted from the later editions and in atlases when maps are traced.

One library has attempted to persuade departments to pay for duplicate sets but with limited success because no one department wishes to assume financial responsibility for sets used by several departments. Three libraries report that they reinforce sections and cover pages with gauze which prolong the life of the material but do not solve the problem. In some cases it is possible to secure new signatures or to purchase a single volume of a set but it is scarcely in the realm of possibility for any library to buy sufficient sets to meet the demand for certain articles which they may contain.

With few exceptions duplicate materials are administered by the reserve book room, are temporarily bound, and cataloged simply, if at all. Drake University files copies in envelopes labeled with the author, title, source, and name of the professor using them. These envelopes are arranged alphabetically and filed in the stacks adjacent to the reserve book room. Cards giving the same information as that on the envelopes but arranged by the source are filed in one drawer of the catalog marked "Typed Articles."

The College of the City of New York mounts on white sheets for legibility copies made on onion skin paper and places them in pamphlet binders. The University of Wyoming gives to copies the classification of the book or periodical from which it is taken and files on the shelf following the source, with a note on the catalog card indicating that copies have been made.

At the Woman's College, University of North Carolina, when a duplicate has 
been cataloged, a note is penciled at the head of the original article stating, "Please use reprint or duplicate of this article for class assignments." Students are required to give paging of articles when requesting periodicals from the stacks, thus giving the librarian at the desk an opportunity to note excessive wear and to notify assistants to refer students to the reprints.

To protect maps from destruction of tracing, Vassar College has collected a group of maps from withdrawn copies of atlases and maps, which may be traced without requesting permission.

\section{Encyclopedia of Social Sciences}

Teachers College, Columbia University, was unable to supply sufficient copies of the Encyclopedia of the Social Sciences for the many required readings in their educational foundations course. The instructional staff arranged with the publisher to select articles for a single volume $^{2}$ which was published in 1937. The library bought volumes for circulation and many students bought their own copies.

Most libraries withdraw original material from circulation during the time when duplicates are in greatest demand; only two libraries refuse to make the material available in any form for large classes.

Library problems given to freshmen and library school students have brought forth both criticism and recommendations. It is the judgment of many librarians that expensive reference sets should not be ruined by immature students working on elementary reference problems or the "socalled research assignments." Emory University limits instruction to the use of the card catalog and the Readers' Guide.

\footnotetext{
${ }^{2}$ Encyclopedia of the Social Sciences. Selections by the Educational Foundations Staff. Macmillan, I937.
}

Copies of the cumulative issues of the Guide are kept so that each student in groups of forty may have a copy for practice work. The University of Wisconsin has prepared microfilms of several pages of the Oxford Dictionary. Teachers have divided classes into small groups and staggered assignments, not to reduce the use of books but to relieve congestion and confusion in the reading rooms. Each student has been asked to examine subjects beginning with the first letter of his name to spread use over larger areas of sets. Two librarians have suggested that a practice collection in a room set aside for practice work would be highly desirable.

\section{Intensity of Feeling}

Intensity of feeling manifested on this entire situation ranges from the "Grin and Bear It" policy to high praise for faculty cooperation on a common problem. Faculty members have assisted by requesting one student or a committee of students to report to the class on periodical articles; by giving a large variety of subjects for themes and not repeating the assignment; by large reserve collections and encouragement of a wide range of reading; by willingness to assist in the preservation of materials when informed of the problem and the limitations of the book fund.

At the beginning of the school year five libraries send form letters to all faculty members explaining the policy of the library. In this communication the University of Washington states under Class Use of Periodicals: " $B y$ vote of the faculty, classes must not be referred to articles in bound periodicals for the following reasons :

I. When all or a considerable number of a large class have read a given article, the 
volume is badly worn at that place, the sewing is likely to be broken, and the pages frequently torn.

2. Almost invariably some one in reading the article checkmarks certain passages and underscores important sentences in ink.

3. Not infrequently pages are actually cut out of the volume so that a particular article is lost and the volume seriously damaged.

4. It is a duty to preserve valuable material for future generations, as well as to make it available for present use.

The letter further states that periodicals may be utilized:

I. By having one student read an article and report on it.

2. By notifying the librarian in advance if it is deemed necessary to have all students actually read a given article. The article will then be duplicated and a number of copies placed on reserve. In the case of a recent magazine, duplicate copies may be obtained if sufficient notice is given.

Iowa State College letter reads in part as follows:

Rare books and periodicals of which duplicate copies are not available and cannot be purchased will not be placed on reserve and cannot be made available for the use of large classes. It is suggested that members of the instructing staff desiring to use material from such books and periodicals arrange one month in advance for mimeographing, duplication, or photostating.

From the experience of many libraries it is evident that no institution has arrived at a solution of the problem under discussion. Moderate success has been achieved through faculty cooperation which seems to be the most logical first approach. Some librarians believe that no further progress can be made until methods of teaching are changed. One writes, "Fortunately, the practice of professors assigning large classes to required reading is decreasing for the very good reason that it is not a satisfactory teaching method."

The matter of duplication is further complicated by the copyright law. The time and inconvenience involved in securing consent to copy materials, the refusal of publishers to allow duplication, and the risk of infringement of the copyright law delay action to the point of being impractical for the demands placed on libraries. It is probably on this point that libraries would profit most by further discussion. 